\title{
Migration aspirations among youth in the Middle East and North Africa region
}

\author{
Raul Ramos
}

AQR-IREA, University of Barcelona \& IZA

Dpt. Econometrics, Statistics and Applied Economics

Av. Diagonal 690, 08034 Barcelona (Spain)

rramos@ub.edu, +34+934024310

http://orcid.org/0000-0003-0047-0793

\begin{abstract}
The Middle East and North Africa region shows high levels of unemployment rates for youth, and the number of youth not in education, employment or training is also among the highest in the world. In this context, migration is one of the more obvious reactions of youth facing unmet aspirations in the labour market. This research analyses the determinants of intentions of youth to migrate during their school-towork transitions in selected countries in this region. With this aim, I use microdata from School-to-Work Transition Surveys conducted by the International Labour Organization from 2013 to 2015 in Egypt, Jordan, Lebanon, Palestine and Tunisia. These surveys targeted a nationally representative sample of young people between 15 and 29 and include data on intentions to migrate (internal and international) and different factors related to social and educational background. Microeconometric models are used in order to achieve a better understanding of factors influencing youth decisions to migrate.
\end{abstract}

\section{Keywords}

Intentions to migrate; youth; unemployment; inactivity; school-to-work transition

\section{JEL Codes}

F22, J61, J65, R23

\section{Acknowledgements}

The author gratefully acknowledges the ILO WORK4YOUTH (W4Y) team for sharing the microdata from the School-to-Work Transition Surveys (SWTS) and the support received from the Spanish Ministry of Economy and Competitiveness through the project ECO2016-75805-R. 


\section{Introduction}

Unemployment rates in the Middle East and North Africa (MENA) region are among the highest in the world, particularly for youth. Youth unemployment rates are usually higher than the overall unemployment rate, but in the MENA region they are more than double, as seen in Figure 1. As Pastore (2018) shows, there is considerable cross-country variation in youth labour market outcomes. The main features of the labour market in the analysed countries in 2015 are shown in Table 1. According to the data shown in Table 1, the participation rate is relatively low (below 50\% in all cases) while the unemployment rate is relatively high, particularly for youth, with values around $20 \%$ for Lebanon and close to $40 \%$ in Palestine.

\section{FIGURE 1}

\section{TABLE 1}

Demographic pressures are a leading cause of high youth unemployment rates in the region, as the labour market has been unable to provide a sufficient number of job opportunities to absorb the new entrants who also face greater difficulties due to their lack of work experience compared to adults (Pastore 2015). A striking feature specific to the region, which can also be observed in Table 1 , is that education is not a guarantee against unemployment or inactivity. Data suggest that youth unemployment rates in the region increase consistently with the level of education attained. In countries such as Egypt or Tunisia, youth who have completed tertiary education are more than two times more likely to be unemployed than those with primary education or less. This contrasts with the situation in most developed and developing regions, where unemployment decreases as the level of education increases (ILO 2015). High unemployment rates for highly skilled youth are a signal of skill mismatches in labour markets across the region. The main reason for these mismatches, according to the Union for the Mediterranean (UfM) ad hoc work group on job creation (2016), is that skills demands are changing rapidly "due to the globalisation of the economy and technological innovation, which in turn speeds up organisational changes in businesses and creates the need for continuous training, also for adults.” Issues related to skills mismatches highlight the inability of education systems in the region to provide graduates with the skills required on the supply 
side of the labour market and the insufficient creation of high-skilled jobs in the economy on the demand side. The attractiveness of public sector jobs partially explains these mismatches, as these jobs provide a series of advantages to a relatively limited pool of workers. The prospect of a public sector job influences youth educational choices, resulting in a workforce with education that is not tailored to the requirements of the private sector (Ahmed et al. 2012; European Commission 2010). ${ }^{1}$ The European Training Foundation (ETF 2015a) reinforces this observation highlighting that despite the declining role of the state in the MENA region, young people's attitudes continue to be driven by the hope of getting a good job in the public sector, leading to a voluntary situation of inactivity while waiting for such an opportunity.

High unemployment rates discourage youth from participating in the labour market (ETF 2015b), and NEET (Not in Employment, Education or Training) rates are high and increasing since the beginning of the 2008 recession (Carcillo et al. 2015). For instance, as it can be seen in Table 1, the NEET rate for youth is between $25 \%$ and $30 \%$ in the considered countries according to the latest estimates of the International Labour Organization (ILO). As shown in this Table, the proportion of NEETs among qualified youth is much higher than the average rate. In sum, youth face more difficulties accessing jobs during their transition from school to work in the MENA countries than in most developed countries (Quintini and Martin 2014; ETF 2015b). This situation partially explains why migration is considered an important option for youth in the region. Labour market conditions are one of the most relevant pull factors explaining migration flows from countries with high unemployment rates to others with better labour prospects or from poorer regions within a country to wealthier ones (UNESCO 2016; OECD 2016). Because many potential migrants from the MENA region are highly qualified, brain drain is a primary concern. Even if the decision to move is from rural to urban areas in the same country, an excess of labour supply in the local urban labour markets can push young migrants into informal employment in a context where they have lost the protection of their families (O’Higgins 2017).

\footnotetext{
${ }^{1}$ European Commission (2010, p. 33): “Guaranteed employment, without concern for productivity in the public sector, led to the prevalent rent-seeking behaviour among graduates and created strong disincentives for work in the productive sectors. The result has been the poor use or even the waste of educated labour by distorting incentives in labour markets."
} 
Table 1 also shows relevant differences in the labour market according to gender. As highlighted in previous literature on MENA countries (see, for instance, Chamlou and Karshenas 2016), women have much lower rates of labour market participation than men and higher unemployment rates. Moreover, the literature on migration has found that men are more likely to migrate than women (Dibeh et al. 2018 for Lebanon; Elbadawy 2011 for Egypt), probably due to family and other social constraints (Van Mol 2016), and, for this reason, male and female youth are analysed separately in this research.

Taking all of this into account, it is important to analyse not only what macroeconomic conditions drive migration, but also those factors at the individual, family, and community level that are also relevant to explain migration decisions. In this context, there is a growing body of literature on adults' motivations for migration (de Haas 2011), but very few empirical analyses devote attention to the specific case of youth (see Williams et al. 2018 for a recent review) and, to the best of my knowledge, no previous research has considered the specific situation of NEETs and their relationship to the brain drain phenomenon. Moreover, much of the empirical research is still destination-country biased, as it is based on interviews with actual migrants about their decision to migrate, but it does not consider those who wanted to migrate but could not do so for several reasons, such as financial constraints, legal barriers, or family ties.

This research adds to the scarce literature on the topic by examining the individual determinants of migration aspirations among youth NEETs in selected MENA countries. Due to the lack of appropriate administrative data in these countries, microdata from School-to-Work Transition Surveys (SWTS) conducted by the International Labour Organization (ILO) from 2013 to 2015 are used in the analysis. ${ }^{2}$ Although the number of observations is reduced in some cases, these surveys constitute a nationally representative sample of young people between 15 and 29 years old and, due to the homogeneity and comparability of the questionnaire, they represent a valuable source of information regarding the lives of young people in the considered countries. SWTS has also been used for other analyses related to school-to-work transitions. In a study elaborated as preparatory work for the UNESCO 2017/8 GEM Report, Pastore (2017) uses SWTS data to study the incidence of Technical and Vocational Education and Training (TVET) on

\footnotetext{
2 More details regarding SWTS can be found at http://www.ilo.org/employment/areas/youth-
} employment/work-for-youth/WCMS 191853/lang--en/index.htm [accessed April 17 th 2019] 
transition to first jobs in 34 developing countries, and Manacorda et al. (2017) use SWTS data to analyse the transition to the first job and to the first stable job for youth in 23 lowand middle-income countries. The SWTS questionnaire includes questions about the willingness to move in order to find a job, making its use appropriate for the objective of this study. In particular, using these data, microeconometric models are used to achieve a better understanding of the determinants of intentions to migrate of youth NEETs during their school-to-work transitions in Egypt, Jordan, Lebanon, Palestine, and Tunisia. The analysis is focused on the particular situation of qualified youth who are inactive or unemployed and who consider the possibility of moving to find a job abroad or in another part of the country. Results are disaggregated by gender in order to capture potential differences among both groups of youth. The topic is particularly interesting from a policy perspective, as geographical mobility is one of the potential mechanisms of adjustment to labour market shocks in developing countries (Lall et al. 2006), but can also generate pressures on urban labour markets if internal migrants do not find appropriate jobs. Regarding international migrants, knowing the profile of potential migrants can also help destination countries to identify the actions required in order to obtain a better integration in the labour market and in society to avoid brain drain (Esipova et al. 2011).

The rest of the article is structured as follows: section 2 summarises the related literature on the individual determinants of migration; section 3 describes the data, methodology, and obtained empirical evidence; and section 4 presents the concluding remarks.

\section{Literature review}

There are many theoretical hypotheses and models concerning the determinants of migration. Gravity models were initially based on Newton's gravity law, but recent contributions have also provided microfoundations in the context of migration analysis (Grogger and Hanson 2011). In particular, migration stocks (or flows) between two countries are supposed to increase in size and decay with the distance between the two countries. Usually, the most representative variable of the size of countries is population. Therefore, it is expected that migration is a positive function of population size of the host and home country and a negative function of distance (which controls for migration costs). Although, the simplest versions of gravity models relate bilateral migration to the relative size of the origin and destination countries and the distance between them, 
additional factors can affect migration flows. For this reason, gravity models are enlarged with variables related to migration pull and push factors, for instance: better economic opportunities in the destination country (i.e., prospects for higher wages or lower unemployment rates), safer conditions or greater political freedom, among others. These models are widely used in the empirical analysis of migration due to their relatively good forecasting performance (Ramos and Suriñach 2017).

However, apart from macroeconomic conditions, it is likely that individual characteristics also play a role. In fact, the literature proposes that migration choices are driven by individual expectations about the labour market in the destination country compared to the origin, but also to some extent by the personal characteristics that make individuals prone to migrate. From an individual perspective, the main economic explanation for the greater incidence of migration among the youth is that it is an investment. Costs include the financial costs of moving, finding a job, and forgone earnings, apart from the psychological costs associated with living in a new environment and leaving the family behind (Hunter et al 2009, Bodvarsson et al 2015). Expected returns are higher for youth, because they have not yet invested in human capital associated with the specific skills required in the origin labour market (McKenzie 2007). The forgone earnings from migrating are also likely to be less for youth, as they experience more difficulties in the labour market than older workers. Regarding other components of human capital, as shown by Docquier et al. (2007), educational level is also expected to influence the migration decision, even in the presence of an imperfect transferability of the knowledge acquired in the home country (Sanromá et al. 2015). Workers with higher levels of human capital are more likely to migrate, as their potential gains are usually higher than those of less qualified workers. Moreover, they not only value pecuniary factors, but other variables such as a better match between their education and their job. Other individual characteristics can also influence the migration decision, reducing the associated costs or the opportunity cost of staying. For instance, command of the language of the destination country reduces the cost of migration (Adserà and Pytliková 2015). Employment status is also expected to play a role. It can be expected that unemployed youth are more likely to seek work abroad when opportunities in the home country are limited.

Contributions from the new economics of migration (Stark and Bloom 1985) highlight that the decision to migrate is often a family decision. From this perspective, migration 
aspirations can also vary depending on the gendered division of tasks within the family. Although Docquier et al. (2012) conclude that there are no significant differences between skilled men and women regarding the incidence of migration, they find that women tend to follow men in a more intensive way than the other way around because of social norms in many developing countries. Being married or having children can also have an effect on migration aspirations. Individuals who have parents with high incomes (or high levels of education) will be more likely to emigrate, as they do not face the liquidity constraints of poorer families to pay for the costs of migration. However, low-income families can also put more pressure on youth, as they have higher incentives to send members of the family abroad in order to receive remittances. It has been well documented that once moved, migrants are likely to move again (DaVanzo 1981, Dustmann and Görlach 2016). Therefore, it can be expected that previous experiences of mobility of the family facilitate migration, as repeated migration implies fewer difficulties adjusting to new environments (Constant et al. 2013). The urbanisation level of the family's place of residence can also influence migration decisions. In particular, youth from rural areas are very likely to move, but at the same time, an individual living in a family settled in an urban area might find it easier to adjust to life in a foreign developed country than someone brought up in a rural area (Lall et al. 2006). Finally, the literature also documents the role of social networks: contacts with migrants abroad facilitate the decision to move. For individuals with family or friends abroad, migration costs are much lower than for those with no contacts abroad (Bauer et al. 2000).

Moving to the empirical literature for the developing countries, ${ }^{3}$ Gibson and McKenzie (2011) are among the first to carry out a specific analysis of the determinants of migration at the individual level by compiling data for Tonga, Papua New Guinea, and New Zealand - three countries in the Pacific region, which has the highest brain drain rate in the world. Their results reveal that although economic variables seem to play a role in explaining migration decisions, variables related to individual preferences are also strong predictors.

\footnotetext{
${ }^{3}$ The literature on the determinants of migration decisions among youth also considers flows between developed countries, particularly within the European Union in the context of the Great Recession. See, for instance, Hadler (2006), Grip et al. (2010), Kahanec and Fabo (2013), Bazillier and Boboc (2016), Van Mol (2016), Ramos and Royuela (2017), and Williams et al. (2018), among others.
} 
Similar results have also been found in the few studies on the MENA region. In particular, Elbadaby (2011) and David and Jarreau (2016) analyse migration intentions in Egypt using different databases. Their results also support the relevance of individual characteristics in explaining migration decisions. In particular, they find that that being unemployed is a significant determinant of migration and that secondary and tertiary education are positively correlated with the emigration decision. They also find a positive impact of family income and social networks on migration aspirations.

Dibeh et al. (2018) analyse the situation in Lebanon. They find that being male and unemployed has a positive impact on migration intentions. University education also increases willingness to emigrate. They also find that youth from poor households have a higher propensity to emigrate than those from richer households.

In sum, both the theoretical and empirical literature on the determinants of migration highlight the relevance of individual characteristics and that more qualified individuals are more open to moving in pursuit of better working conditions, particularly if their employment status is unsatisfactory. In the next section, whether these predictions hold for the specific case of youth NEETs in select MENA countries or not is tested empirically.

\section{Empirical evidence}

The analysis in this research uses microdata from the ILO's SWTS. The STWS includes in-depth information concerning the labour market situation of young men and women and identifies the factors that can facilitate their school-to-work transition. As mentioned, these surveys targeted a nationally representative sample of young people between 15 and 29 years old and were carried out in more than 30 countries between 2012 and 2016. Our analysis is limited to the MENA countries where the survey was carried out: Egypt, Jordan, Lebanon, Palestine, and Jordan. In particular, the sample used in this study is formed by 2,582 individuals with ages between 15 and 29 years old. Sampling weights have been used in all computations.

The SWTS questionnaire provides detailed information on individual characteristics such as gender, age, marital status, having children or not, educational status, and employment 
status. For unemployed or inactive youth, it also provides information on barriers to entry into the labour market and willingness to move in order to find a job. It also provides information on the place of residence (urban/rural) and on parents' educational background and the financial conditions of the household. Appendix 1 provides a statistical description of the variables considered in the analysis, and Appendix 2 refers to variable definition in the SWTS' original microdata files, which can be useful for replication purposes.

Before moving to the results from the econometric analysis, Table 2 shows that the willingness to move to find work among NEETs according to the ILO-SWTS survey varies from $20.9 \%$ in Lebanon to $36.7 \%$ in Tunisia. As expected, in all of the considered countries except Palestine, the percentage of youth who would be willing to move to other parts of their country to find a job is substantially higher than those who would consider moving to a foreign country. The share of youth who would consider moving abroad varies from $6.1 \%$ in Jordan to $19.4 \%$ in Palestine. When considering the willingness to move among NEETs with tertiary degrees, these figures are similar to those described for all NEETs with the exception of Lebanon, where this percentage is substantially lower. Their preferences regarding internal versus international mobility are also similar. Gender differences are substantial for all considered countries: without exception, female youth NEETs are much less willing to move to find work than male youth. However, as is the case for young men, there is a clear preference for internal mobility rather than international migration among young women. As before, the only exception is Palestine.

\section{TABLE 2}

To identify the determinants of youth NEET migration intentions, probit models are used to predict the probability of expectations to move to find work. Among the key explanatory variables, and taking into account the results of previous studies, the following regressors are included: a dummy variable for living in a rural area or not, gender, age, marital status, having children or not, having a highly qualified father or not, a dummy for previous mobility, two dummies related to the family financial conditions (good and bad compared to average), a dummy for tertiary studies, a dummy that indicates whether the individual worked while studying or not, and a dummy capturing those individuals who did not finish the last level of formal education that they started. Due to 
the reduced sample size for some countries, the different data sets are pooled and country fixed effects are included as additional explanatory variables. The inclusion of country fixed effects controls for cross-sectional variation associated with each country, including country-specific push factors. Standard errors are also clustered by country, and individual sampling weights are used in all the models described below. Models are first estimated for all youth, and separated models are estimated for males and females to check if the considered drivers of migration intentions have differentiated gender effects.

The first column of Table 3 shows the marginal effects calculated at means after estimating the probit model by maximum likelihood for youth NEETs in the sample. Living in a rural area reduces the probability of moving to find work by -0.015 probability points compared to an individual living in an urban area. Age does not have any significant effect on the probability of migration aspirations. At this point, it is important to remember that a sample of youth between 15 and 29 years old is considered in this research. Regarding gender, being female strongly decreases the probability of moving to find work - a similar result to the findings of Dibeh et al. (2018) for Lebanon and Elbadawy (2011) for Egypt, although opposite to the one found for most developing countries (particularly high skilled ones, see Docquier et al. 2012). Marital status, having children, and previous experiences of mobility do not seem to affect the probability of migration. Having a father with high qualifications has a positive effect on migration aspirations, although living in a household with good financial conditions has the opposite effect. As expected, having completed tertiary studies increases the probability of having migration aspirations by 0.0675 probability points, a result that is in line with the literature. Working while studying has a positive effect on migration probability, while those who have drop out of school have significantly lower migration aspirations. Finally, the country dummy variables show that migration aspirations are higher in all the considered countries than in Lebanon (base category), although the willingness to move is much higher in Jordan, Tunisia, and Egypt than in Palestine.

\section{TABLE 3}

Model 2 in Table 3 adds a dummy variable taking value 1 in case of unemployment and 0 in case of inactivity. While results for the other explanatory variable do not show relevant variations from what has been previously described, being unemployed increases 
the probability of migration aspirations by 0.0418 probability points, in line with the findings of David and Jarreau (2016) for Egypt and Dibeh et al. (2018) for Lebanon. Model 3 replaces this variable with a new set of dummies, where unemployment status is disaggregated into four statuses according to the duration of unemployment. Only the dummy associated with a length of unemployment between three and six months is statistically significant. It seems that willingness to move increases after some months of unemployment, but then decreases, probably due to a discouragement effect. Model 4 in Table 3 adds three additional variables related to the main obstacles to finding employment as perceived by individuals (the base category is no obstacle or other obstacle with minority answers such as too young or not enough experience). The only obstacle that seems to reduce migration aspirations is the lack of appropriate skills.

Table 4 presents the results of estimating model 4 in Table 3 separately for men and women. To facilitate the comparison, the first column replicates the last column of Table 3. The second column shows the results for men and the third column for women. As it can be seen, living in a rural urban area affects the probability of moving to find work differently for men than for women: while it increases for men, it clearly decreases for women, a similar result to the one found by Elbadaby (2011) for Egypt. As already found by Mckenzie (2007), being married reduces the willingness to move for women, but not for men. The same applies to living in a household with good financial conditions. Having completed tertiary studies increases the probability of having migration aspirations for women, but not for men in line with Mckenzie (2012). Working while studying has a positive effect on migration probability for men, while the negative effect of having dropped out of school is similar for men and women. Regarding the main obstacles to finding employment, the lack of appropriate skills reduces migration aspirations for men and women, while low wages and the lack of jobs negatively affect the mobility decisions of men. Another interesting result related to obstacles to finding a job is that low wages seem to be the main factor behind the intentions to migrate among women. In the case of women, receiving low wages could be related to a number of factors, including employers' discrimination, predominant social norms, or attitudes limiting what constitutes appropriate employment for women (European Commission, 2010). Finally, regarding country dummies, there are no remarkable gender differences and results are similar to those in Table 3. 


\section{TABLE 4}

Table 5 presents the results of estimating a probit model similar to the model in Table 4 but allowing for the possibility of heterogeneous effects of having a tertiary degree across the considered countries. With the exception of Lebanon, where having a tertiary degree does not affect migration aspirations, in the rest of the considered countries it has a positive and significant effect when considering the whole sample. In particular, having a tertiary degree increases the probability of migration intentions by 0.134 probability points in Jordan and 0.126 in Palestine. In Tunisia and Egypt, the marginal effects are lower, at 0.0585 and 0.0482 , respectively. As before, there are significant gender differences. For men, having a tertiary degree increases the probability of migration intentions in Egypt, Jordan, and Palestine while it has no significant effect in Lebanon and a negative effect in Tunisia. For women, the positive impact of having a tertiary degree is much higher than for men in Egypt, and in Tunisia it clearly increases intentions to migrate. However, marginal effects are negative in Lebanon and Palestine and are not statistically significant in Jordan.

\section{TABLE 5}

In order to check if the determinants of the willingness to move abroad are different from those of youth who would consider moving to other parts of the country, Table 6 presents the results a probit model estimation of the probability of moving abroad using information on individuals who have stated that they would be willing to move. As in Table 4, the first column presents the results for the whole sample, and the second and third column presents the results for men and women, respectively. The factors explaining willingness to move seem to be quite different when considering the possibility of international versus internal migration. Youth NEETs living in rural areas have nearly $30 \%$ more probability of moving abroad than those living in urban areas. Age has a positive and significant effect, while being female discourages international migration for work reasons. Marital status, having children, the educational level of the father, and previous mobility are not statistically significant. However, living in a household with bad financial conditions clearly encourages the decision to move abroad rather than moving to other parts of the country. More qualified youth have more aspirations to migrate abroad in Jordan and Palestine than qualified youth in Egypt. In Tunisia, qualified 
youth prefer to move to other parts of the country instead of abroad, and the same happens in Lebanon, where all of the qualified youth in the sample report a preference for internal versus international migration. Longer periods of unemployment also encourage youth NEETs to consider the possibility of moving abroad. Regarding the main obstacles to finding employment, those who perceived that the main problem was the lack of jobs are are more willing to move to another country to find work. Finally, regarding country fixed effects, after having controlled for the remaining individual characteristics, youth living in Palestine and Tunisia are found to have higher aspirations to migrate abroad, while the opposite happens in Egypt and Jordan when compared to Lebanon. Although the sample size when disaggregating by gender is relatively small (particularly for women), some interesting results can also be observed in the last two columns of Table 6. Living in a rural area has similar effects for men and women. Age, good financial conditions, work while studying, and unemployment duration are mainly relevant for men, while bad financial conditions and dropouts are relevant factors for women. In fact, the different effect of some of these factors by gender also suggest that there is room for policies that specifically support a better labour integration of high qualified youth in origin countries as a way to reduce the incentives to migrate abroad. In particular, it seems that reforming active labour market policies in order to reduce unemployment duration would be a good option for men, while for women it would be important to reduce school dropouts and improving their access to better paid jobs or to provide economic incentives for selfemployment as a way to improve their financial conditions in origin countries.

\section{TABLE 6}

\section{Concluding remarks}

This research identifies a number of socioeconomic characteristics that negatively impact youth employability in select MENA countries and increase their willingness to emigrate.

The obtained empirical evidence shows that, on one hand, young NEETs are a heterogenous group regarding gender, level of qualifications, and the interaction between those factors. In fact, the proportion of NEETs across qualified young individuals is much higher than for non qualified ones. Taking this evidence together with the very high unemployment rates among qualified workers in the considered countries, this might be 
a sign of a mismatch between the demand and supply sides of the labour market. These countries seem to be producing too many university graduates, or too many graduates with degrees that the labour market does not sufficiently demand. On the other hand, the results show that a significant proportion of qualified and unqualified NEETs are willing to move to find a job. More qualified youth have more aspirations to migrate abroad in Jordan and Palestine than those in Egypt. In Tunisia, qualified youth prefer to move to other parts of the country instead of abroad, and the same happens in Lebanon. Living in rural areas or in a household with bad financial conditions encourage the decision to migrate abroad instead of moving to other parts of the country. Longer unemployment spells and the perception of a lack of jobs are also relevant drivers for considering international migration.

It is worth mentioning that this research has several limitations: first, the analysis relies on cross-sectional datasets, while migration decisions are dynamic, pointing to the need for longitudinal datasets that are unavailable for the considered countries. Second, the SWTS do not contain any information on youth social networks (a key factor according to Cummings et al. 2015) or on the desired destination countries in the case of international migration. There is still room to improve our knowledge of the individual determinants of migration decisions (for instance, those related to personality as suggested by Gibson and McKenzie 2011).

However, and taking into account the previous caveats, some policy recommendations can be derived from the obtained empirical evidence. First, the high NEET rates among qualified youth clearly point to the need to improve education and training systems to better match the requirements of the labour market. At the same time, continuous vocational and educational training is required for unskilled workers who also face unemployment or inactivity, a recommendation in line with the recent findings of Pastore (2017) in his background paper for the 2017/8 UNESCO Global Education Monitoring Report. Moreover, reforming the school-to-work transition system might also help MENA countries to develop and improve their institutional settings, although the potential capacity of these kinds of reforms to generate new jobs is relatively limited, as highlighted by Pastore (2018). Second, labour regulations in MENA countries only provide a very low level of protection for workers and, particularly for youth. As a result, labour market segmentation between informal and formal labour markets and between 
private/public occupations in urban and rural areas exerts additional pressure on migration intentions among youth. For this reason, a high proportion of NEETs are willing to move to other parts of the country to find work. These migratory flows can alleviate pressure in some areas but, at the same time, an excess of labour supply in more dynamic labour markets can push young migrants into informal jobs and depress wages in formal jobs. Finally, as qualified youth have stronger preferences to move abroad, a potential negative effect is brain drain in the origin country. It is important to consider those factors than can facilitate their integration in the labour market of the country of destination. The (near) lack of experience of youth immigrants in their home countries and the possibility of skills mismatches in their new jobs imply a risk that they will remain permanently trapped in bad jobs. For this reason, the design of a system of assessment and recognition of foreign-acquired educational degrees would help to give an appropriate signal to the labour market and facilitate a better match between education and jobs. In this sense, providing informal training to recently arrived immigrants would also improve the transferability of their skills to the new labour market (Nieto et al. 2015).

\section{References}

Adserà A, Pytliková M (2015) The role of language in shaping international migration. Econ J 125 (586): F49-F81.

Ahmed M, Guillaume D, Furceri D (2012) Youth unemployment in the MENA region: Determinants and challenges in addressing the 100 million youth challenge. Perspectives on youth employment in the Arab world in 2012, World Economic Forum, Geneva.

Bauer T, Epstein G, Gang I N (2000) What are migration networks. IZA DP No 200, Bonn.

Bazillier R, Boboc C (2016) Labour migration as a way to escape from employment vulnerability? Evidence from the European Union Appl Econ Lett 23(16): 1149-1152. Bodvarsson Ö B, Simpson N B, Sparber C (2015) Migration theory. In Chiswick B R, Miller P W (eds), Handbook of the Economics of International Migration, North-Holland, Amsterdam, pp. 3-51.

Carcillo S, Fernández R, Königs S, Minea A.(2015) NEET youth in the aftermath of the crisis: Challenges and policies, OECD Social, Employment and Migration Working Papers 164, OECD Publishing, Paris. 
Chamlou N, Karshenas M (eds.) (2016) Women work and welfare in the Middle East and North Africa. The role of socio-demographics, Entrepreneurship and Public Policies, Imperial College Press, London.

Constant A F, Nottmeyer O, Zimmermann K F (2013) The Economics of circular migration. In A F Constant and KF Zimmermann (eds): International Handbook on the Economics of Migration, Edward Elgar, Cheltenham, pp. 55-74.

Cummings C, Pacitto J, Lauro D, Foresti M (2015) Why people move: understanding the drivers and trends of migration to Europe, ODI Working Paper 430, London.

DaVanzo J (1981) Repeat migration, information costs, and location-specific capital Popul Environ 4 (1): 45-73.

David A, Jarreau J (2016) Determinants of emigration: Evidence from Egypt, Economic Research Forum (ERF) Working Paper 987, Cairo.

de Haas H (2011) The determinants of international migration, IMI Working Paper Series 32, Amsterdam.

Dibeh G, Fakih A, Marrouch W (2018) Decision to emigrate amongst the youth in Lebanon. Int Mig 56 (1): 5-22.

Docquier F, Lohest O, Marfouk A (2007) Brain drain in developing countries. World Bank Econ Rev 21(2): 193-218.

Docquier F, Marfouk S, Salomone S, Sekkat K (2012) Are skilled women more migratory than skilled men. World Dev 40(2): 251-265.

Dustmann C, Görlach, J-S (2016) The economics of temporary migrations. J Econ Lit 54(1): 98-136.

Elbadawy A (2011) Migration aspirations among young people in Egypt: Who desires to migrate?. Economic Research Forum (ERF) Working Paper 619, Cairo.

Esipova N, Ray J, Pugliese A (2011) Gallup world poll: The many faces of global migration. IOM Migration Research Series 43, Grand-Saconnex.

European Commission (2010) Labour markets performance and migration flows in Arab Mediterranean countries: Determinants and effects. European Commission Occasional Paper 60, Brussels.

ETF (2015a) NEETs: An overview in ETF partner countries, ETF Report, Turin. ETF (2015b) The challenge of youth employability in Arab Mediterranean countries: The role of active labour market programmes, ETF Report, Turin.

Gibson J, McKenzie D (2011) The microeconomic determinants of emigration and return migration of the best and brightest: Evidence from the Pacific. J Dev Econ 95(1): 18-29. 
Grip A de, Fouarge D, Sauermann J (2010) What affects international migration of European science and engineering graduates?. Economics of Innovation and New Technology 19(5): 407-421.

Grogger J, Hanson G H (2011) Income maximization and the selection and sorting of international migrants. J Dev Econ 95 (1): 42-57.

Hadler M (2006) Intentions to migrate within the European Union: A challenge for simple economic macro-level explanations. Eur Soc 8 (1): 111-140.

Hunter R S, Oswald A J, Charlton B G (2009) The elite brain drain, Econ J 119 (538): F231-F251.

ILO (2015) World employment and social outlook: The changing nature of jobs, Geneva. Kahanec M, Fabo B (2013) Migration strategies of the crisis-stricken youth in an enlarged European Union. Transfer 19(3): 365-380.

Lall S, Selod H, Shalizi Z (2006) Rural-urban migration in developing countries: A survey of theoretical predictions and empirical findings, World Bank Policy Research Working Paper 3915, Washington DC.

Manacorda M, Rosati F C, Ranzani M, Dachille G (2017) Pathways from school to work in the developing world. IZA Journal of Labor \& Development 6(1): 1-40.

McKenzie D J (2007) A profile of the World's young developing country migrants, IZA DP 2948, Bonn.

Nieto S, Matano A, Ramos R (2015) Educational mismatches in the EU: Immigrants vs. Natives. Int J Manpower 36 (4): 540-561.

OECD (2016) International Migration Outlook 2016, OECD Publishing, Paris.

O’Higgins N (2017) Rising to the youth employment challenge: New evidence on key policy issues. International Labour Office, Geneva.

Pastore F (2015) The youth experience gap: Explaining national differences in the schoolto-work transition. Heidelberg: Springer.

Pastore F (2017) TVET in developing countries through the second wave of the ILO SWTSs. Background Paper Prepared for the 2017/8 Global Education Monitoring Report, UNESCO, Paris.

Pastore F (2018) Why is youth unemployment so high and different across countries?. IZA World of Labor 2018(420): 1-11.

Quintini G, Martin S (2014) Same but different: School-to-work transitions in emerging and advanced economies, OECD Social, Employment and Migration Working Papers 154, OECD Publishing, Paris. 
Ramos R, Royuela V (2017) Graduate migration in Spain: the impact of the Great Recession on a low-mobility country. In Corcoran J, Faggian A (eds) Graduate Migration and Regional Development, Edwar Elgar Publishing, Cheltenham.

Ramos R, Suriñach J (2017) A gravity model of migration between ENC and EU. Tijdschr Econ Soc Ge 108 (1): 21-35.

Sanromá E, Ramos R, Simón H (2015) How relevant is the origin of human capital for immigrant wages? Evidence from Spain. J Appl Econ 18 (1): 149-172.

Stark O, Bloom D (1985) The new economics of labour migration. Am Econ Rev 75 (2): 173-178.

Union for the Mediterranean (UfM) Ad hoc working group on job creation (2016). Outcome Document, Union for the Mediterranean, Barcelona.

UNESCO (2016) Global education monitoring report, education for people and planet: creating sustainable futures for all, UNESCO, Paris.

Van Mol C (2016) Migration aspirations of European youth in times of crisis J Youth Stud 19(10): 1303-1320.

Williams A M, Jephcote C, Janta H, Li G (2018) The migration intentions of young adults in Europe: A comparative multilevel analysis. Popul Space Place 24(1): 1-16. 
Figure 1. Unemployment rate (UR) and Youth unemployment rate (YUR) in world regions in 2015.

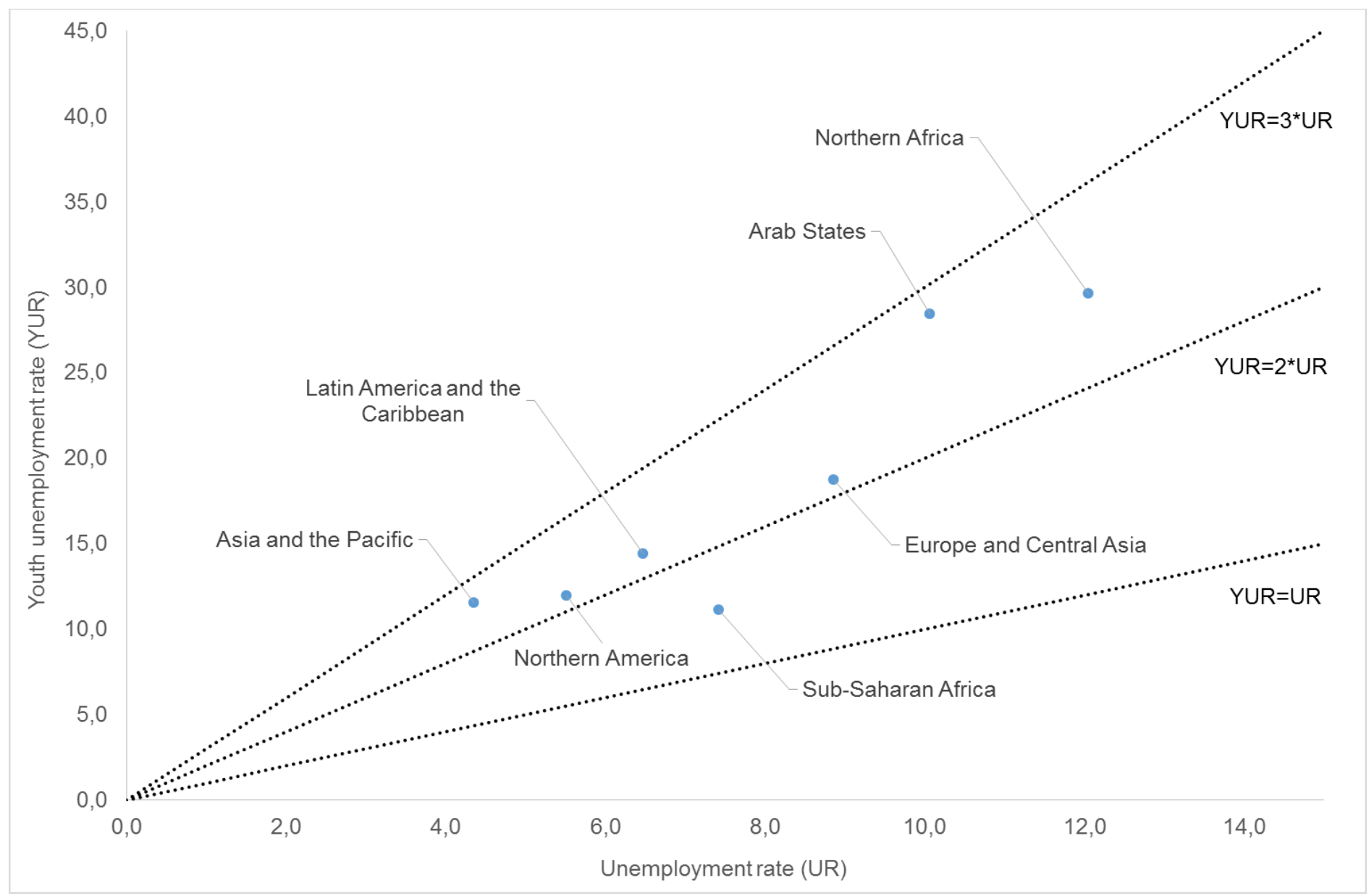

Source: Own elaboration from ILOSTAT data. 
Table 1. Main features of the labour market in selected MENA countries

\begin{tabular}{lccccc}
\hline Total & Egypt & Jordan & Lebanon & Palestine & Tunisia \\
\hline Participation rate (\%) & 48.1 & 40.0 & 47.0 & 45.8 & 47.4 \\
Unemployment rate (\%) & 13.1 & 13.1 & 6.2 & 25.8 & 15.9 \\
Unemployment rate - tertiary level education (\%) & 21.6 & 15.8 & 11.0 & 31.8 & 30.2 \\
NEET rate (\%) & 33.5 & 30.8 & 14.4 & 32.0 & 31.1 \\
NEET rate for those with tertiary education (\%) & 52.0 & 45.6 & 27.5 & 66.0 & 56.7 \\
Youth participation rate (\%) & 32.0 & 23.2 & 29.7 & 32.8 & 33.3 \\
Youth unemployment rate (\%) & 31.6 & 33.3 & 15.8 & 40.5 & 34.7 \\
Ratio youth unemployment rate / unemployment rate & 2.4 & 2.5 & 2.5 & 1.6 & 2.2 \\
Youth NEET rate (\%) & 27.6 & 24.6 & n.a. & 32.1 & 25.4 \\
\hline Male & Egypt & Jordan & Lebanon & Palestine & Tunisia \\
\hline Participation rate (\%) & 70.5 & 59.7 & n.a. & 71.9 & 70.0 \\
Unemployment rate (\%) & 9.4 & 11.0 & 5.8 & 22.4 & 13.3 \\
Unemployment rate - tertiary level education (\%) & 15.2 & 11.0 & n.a. & 17.2 & 20.1 \\
Youth participation rate /\%) & 42.9 & n.a. & n.a. & 53.0 & 44.5 \\
Youth unemployment rate (\%) & 28.5 & 28.1 & 16.3 & 36.2 & 33.4 \\
Ratio youth unemployment rate / unemployment rate & 3.0 & 2.6 & 2.8 & 1.6 & 2.5 \\
Youth NEET rate (\%) & 19.8 & 15.2 & n.a. & 26.4 & 21.2 \\
\hline Female & Egypt & Jordan & Lebanon & Palestine & Tunisia \\
\hline Participation rate (\%) & 22.7 & 12.6 & n.a. & 19.1 & 25.6 \\
Unemployment rate (\%) & 24.8 & 22.7 & 7.4 & 39.1 & 23.0 \\
Unemployment rate - tertiary level education (\%) & 32.8 & 24.0 & n.a. & 49.5 & 42.0 \\
Youth participation rate (\%) & 20.7 & n.a. & n.a. & 11.6 & 21.4 \\
Youth unemployment rate (\%) & 38.3 & 55.8 & 14.6 & 60.4 & 37.7 \\
Ratio youth unemployment rate / unemployment rate & 1.5 & 2.5 & 2.0 & 1.5 & 1.6 \\
Youth NEET rate (\%) & 35.8 & 34.8 & n.a. & 38.1 & 29.9 \\
\hline Patip & & & \\
& & &
\end{tabular}

Participation rate is defined as the ratio between the number of persons in the labour force (employed and unemployed) divided by the working age population. Although not reported, the inactivity rate is equal to 100 minus the participation rate. The unemployment rate is calculated as the quotient between the number of unemployed persons and the total number of persons in the labour force. NEET rate is defined as the number of persons not in education, employment or training as a percentage of total population. Indicators for youth refer to persons between 15 and 24 years old (inclusive).

Most data refer to 2015 or to the latest year available. In the case of Tunisia, they mostly refer to 2013. n.a.: not available.

Source: Own elaboration from ILOSTAT data. 
Table 2. Willingness to move to find work among youth NEETs

\begin{tabular}{|c|c|c|c|c|c|c|c|c|c|c|c|c|c|c|c|}
\hline & \multicolumn{3}{|c|}{ Egypt } & \multicolumn{3}{|c|}{ Jordan } & \multicolumn{3}{|c|}{ Lebanon } & \multicolumn{3}{|c|}{ Palestine } & \multicolumn{3}{|c|}{ Tunisia } \\
\hline & Total & Male & Female & Total & Male & Female & Total & Male & Female & Total & Male & Female & Total & Male & Female \\
\hline Mobility (\%) & 31.8 & 64.6 & 13.9 & 33.7 & 47.8 & 23.1 & 20.9 & 28.5 & 11.8 & 26.8 & 33.4 & 19.7 & 36.7 & 46.6 & 25.9 \\
\hline Internal mobility (\%) & 22.1 & 37.4 & 13.7 & 27.6 & 35.9 & 21.4 & 13.5 & 16.2 & 10.3 & 7.5 & 6.4 & 8.6 & 24.3 & 26.5 & 22.0 \\
\hline International mobility (\%) & 9.8 & 27.2 & 0.2 & 6.1 & 11.9 & 1.7 & 7.3 & 12.2 & 1.5 & 19.4 & 26.9 & 11.1 & 12.4 & 20.1 & 3.9 \\
\hline $\begin{array}{l}\text { Mobility among those } \\
\text { with tertiary studies (\%) }\end{array}$ & 35.1 & 69.4 & 18.9 & 35.4 & 71.2 & 24.8 & 12.6 & 44.4 & 7.3 & 25.5 & 44.5 & 20.0 & 37.8 & 45.3 & 34.0 \\
\hline $\begin{array}{l}\text { Internal mobility among } \\
\text { those with tertiary studies (\%) }\end{array}$ & 25.8 & 40.6 & 18.9 & 28.4 & 50.6 & 22.0 & 12.6 & 44.4 & 7.3 & 7.5 & 4.8 & 8.2 & 32.2 & 38.2 & 29.0 \\
\hline $\begin{array}{l}\text { International mobility among } \\
\text { those with tertiary studies (\%) }\end{array}$ & 9.2 & 28.7 & 0.0 & 7.0 & 21.3 & 2.9 & 0.0 & 0.0 & 0.0 & 18.0 & 39.6 & 11.8 & 5.7 & 7.0 & 5.0 \\
\hline
\end{tabular}

Source: Own elaboration from ILO-SWTS 2013-2015 
Table 3. Probit marginal effects of the intentions to migrate of youth NEETs

\begin{tabular}{|c|c|c|c|c|}
\hline Full sample & $(1)$ & $(2)$ & $(3)$ & $(4)$ \\
\hline Live in rural area & $\begin{array}{c}-0.0147^{*} \\
(0.0084)\end{array}$ & $\begin{array}{c}-0.0170^{*} \\
(0.0098)\end{array}$ & $\begin{array}{c}-0.0195 * * \\
(0.0095)\end{array}$ & $\begin{array}{c}-0.0194^{*} \\
(0.0101)\end{array}$ \\
\hline Age & $\begin{array}{c}0.0020 \\
(0.0028)\end{array}$ & $\begin{array}{c}0.0020 \\
(0.0027)\end{array}$ & $\begin{array}{c}0.0026 \\
(0.0029)\end{array}$ & $\begin{array}{c}0.0019 \\
(0.0028)\end{array}$ \\
\hline Female & $\begin{array}{c}-0.4042 * * * \\
(0.0847)\end{array}$ & $\begin{array}{c}-0.3978 * * * \\
(0.0845)\end{array}$ & $\begin{array}{c}-0.4011^{* * *} \\
(0.0891)\end{array}$ & $\begin{array}{c}-0.3994 * * * \\
(0.0876)\end{array}$ \\
\hline Married & $\begin{array}{r}-0.0669 \\
(0.0583)\end{array}$ & $\begin{array}{r}-0.0635 \\
(0.0590)\end{array}$ & $\begin{array}{c}-0.0765 \\
(0.0553)\end{array}$ & $\begin{array}{l}-0.0666 \\
(0.0547)\end{array}$ \\
\hline Have children & $\begin{array}{c}0.0015 \\
(0.0275)\end{array}$ & $\begin{array}{c}0.0047 \\
(0.0305)\end{array}$ & $\begin{array}{c}0.0132 \\
(0.0322)\end{array}$ & $\begin{array}{c}0.0077 \\
(0.0290)\end{array}$ \\
\hline Father qualified & $\begin{array}{l}0.0238 * \\
(0.0138)\end{array}$ & $\begin{array}{c}0.0221 \\
(0.0145)\end{array}$ & $\begin{array}{c}0.0210 \\
(0.0167)\end{array}$ & $\begin{array}{c}0.0218 \\
(0.0164)\end{array}$ \\
\hline Previous mobility & $\begin{array}{l}-0.0143 \\
(0.0432)\end{array}$ & $\begin{array}{l}-0.0124 \\
(0.0425)\end{array}$ & $\begin{array}{l}-0.0151 \\
(0.0448)\end{array}$ & $\begin{array}{l}-0.0186 \\
(0.0423)\end{array}$ \\
\hline Good financial conditions & $\begin{array}{c}-0.0714^{* * *} \\
(0.0107)\end{array}$ & $\begin{array}{c}-0.0724^{* * *} \\
(0.0111)\end{array}$ & $\begin{array}{c}-0.0755 * * * \\
(0.0105)\end{array}$ & $\begin{array}{c}-0.0752 * * * \\
(0.0107)\end{array}$ \\
\hline Bad financial conditions & $\begin{array}{l}-0.0035 \\
(0.0436)\end{array}$ & $\begin{array}{l}-0.0045 \\
(0.0444)\end{array}$ & $\begin{array}{l}-0.0027 \\
(0.0457)\end{array}$ & $\begin{array}{l}-0.0019 \\
(0.0471)\end{array}$ \\
\hline Tertiary studies & $\begin{array}{c}0.0675 * * * \\
(0.0173)\end{array}$ & $\begin{array}{c}0.0615 * * * \\
(0.0183)\end{array}$ & $\begin{array}{c}0.0604 * * * \\
(0.0168)\end{array}$ & $\begin{array}{c}0.0574 * * * \\
(0.0164)\end{array}$ \\
\hline Work while studying & $\begin{array}{c}0.0318 * \\
(0.0176)\end{array}$ & $\begin{array}{c}0.0283 \\
(0.0173)\end{array}$ & $\begin{array}{c}0.0248 \\
(0.0166)\end{array}$ & $\begin{array}{c}0.0245 \\
(0.0162)\end{array}$ \\
\hline Dropout & $\begin{array}{c}-0.0882 * * * \\
(0.0098)\end{array}$ & $\begin{array}{c}-0.0875^{* * *} \\
(0.0105)\end{array}$ & $\begin{array}{c}-0.0891 * * * \\
(0.0116)\end{array}$ & $\begin{array}{c}-0.0877 * * * \\
(0.0100)\end{array}$ \\
\hline Unemployed & & $\begin{array}{l}0.0418 * \\
(0.0219)\end{array}$ & & \\
\hline Unemployed for 3 months or less & & & $\begin{array}{l}-0.0251 \\
(0.0257)\end{array}$ & $\begin{array}{l}-0.0236 \\
(0.0299)\end{array}$ \\
\hline Unemployed between 3 and 6 months & & & $\begin{array}{c}0.1029 * * * \\
(0.0386)\end{array}$ & $\begin{array}{c}0.1065 * * * \\
(0.0350)\end{array}$ \\
\hline Unemployed between 6 and 12 months & & & $\begin{array}{c}0.0262 \\
(0.0495)\end{array}$ & $\begin{array}{c}0.0326 \\
(0.0524)\end{array}$ \\
\hline Unemployed for more than 12 months & & & $\begin{array}{c}0.0242 \\
(0.0207)\end{array}$ & $\begin{array}{c}0.0300 \\
(0.0184)\end{array}$ \\
\hline Main obstacle in finding employment - Lack of skills & & & & $\begin{array}{c}-0.0758 * * * \\
(0.0262)\end{array}$ \\
\hline Main obstacle in finding employment - Low wages & & & & $\begin{array}{c}0.0075 \\
(0.0334)\end{array}$ \\
\hline Main obstacle in finding employment - Lack of jobs & & & & $\begin{array}{l}-0.0322 \\
(0.0277)\end{array}$ \\
\hline Egypt & $\begin{array}{c}0.1396 * * * \\
(0.0110)\end{array}$ & $\begin{array}{c}0.1442 * * * \\
(0.0131)\end{array}$ & $\begin{array}{c}0.1542 * * * \\
(0.0145)\end{array}$ & $\begin{array}{c}0.1722 * * * \\
(0.0124)\end{array}$ \\
\hline Jordan & $\begin{array}{c}0.2007 * * * \\
(0.0191)\end{array}$ & $\begin{array}{c}0.2091 * * * \\
(0.0237)\end{array}$ & $\begin{array}{c}0.2297 * * * \\
(0.0302)\end{array}$ & $\begin{array}{c}0.2527 * * * \\
(0.0226)\end{array}$ \\
\hline Palestine & $\begin{array}{c}0.0761 * * * \\
(0.0125)\end{array}$ & $\begin{array}{c}0.0850 * * * \\
(0.0172)\end{array}$ & $\begin{array}{c}0.1063 * * * \\
(0.0220)\end{array}$ & $\begin{array}{c}0.1337 * * * \\
(0.0174)\end{array}$ \\
\hline Tunisia & $\begin{array}{c}0.1753^{* * *} \\
(0.0105)\end{array}$ & $\begin{array}{c}0.1781^{* * *} \\
(0.0107)\end{array}$ & $\begin{array}{c}0.1960 * * * \\
(0.0169)\end{array}$ & $\begin{array}{c}0.2043 * * * \\
(0.0147)\end{array}$ \\
\hline Observations & 2,582 & 2,582 & 2,582 & 2,582 \\
\hline
\end{tabular}

The reference individual lives in a rural area, he is a male, unmarried, without children, with an unqualified father, without previous experiences of mobility, lives in a household with average financial conditions, he has less than tertiary studies and has not worked while studying and not dropout from school before finishing studies. He lives in the Lebanon. In models (2) to (4) he is also inactive and in model (4) he has not found lack of skills, low wages or lack of jobs to be a main obstacle in finding a job. Standard errors clustered by country in parentheses.

$* * * \mathrm{p}<0.01, * * \mathrm{p}<0.05, * \mathrm{p}<0.1$ 
Table 4. Probit marginal effects of the intentions to migrate - Analysis by gender

\begin{tabular}{|c|c|c|c|}
\hline & All & Males & Females \\
\hline \multirow[t]{2}{*}{ Live in rural area } & $-0.0194 *$ & $0.1522 * * *$ & $-0.1108 * * *$ \\
\hline & $(0.0101)$ & $(0.0313)$ & (0.0189) \\
\hline \multirow[t]{2}{*}{ Age } & 0.0019 & -0.0005 & 0.0032 \\
\hline & $(0.0028)$ & $(0.0048)$ & $(0.0024)$ \\
\hline \multirow[t]{2}{*}{ Female } & $-0.3994 * * *$ & & \\
\hline & $(0.0876)$ & & \\
\hline \multirow[t]{2}{*}{ Married } & -0.0666 & -0.0231 & $-0.0735 *$ \\
\hline & $(0.0547)$ & $(0.1796)$ & $(0.0378)$ \\
\hline \multirow[t]{2}{*}{ Have children } & 0.0077 & -0.0107 & 0.0226 \\
\hline & $(0.0290)$ & $(0.1610)$ & $(0.0311)$ \\
\hline \multirow[t]{2}{*}{ Father qualified } & 0.0218 & $0.0558 *$ & -0.0027 \\
\hline & $(0.0164)$ & $(0.0306)$ & $(0.0093)$ \\
\hline \multirow[t]{2}{*}{ Previous mobility } & -0.0186 & -0.0508 & 0.0043 \\
\hline & $(0.0423)$ & $(0.0622)$ & $(0.0235)$ \\
\hline \multirow[t]{2}{*}{ Good financial conditions } & $-0.0752 * * *$ & 0.0099 & $-0.0634^{* * *}$ \\
\hline & $(0.0107)$ & $(0.0813)$ & $(0.0162)$ \\
\hline \multirow[t]{2}{*}{ Bad financial conditions } & -0.0019 & 0.0010 & -0.0305 \\
\hline & $(0.0471)$ & $(0.0424)$ & $(0.0373)$ \\
\hline \multirow[t]{2}{*}{ Tertiary studies } & $0.0574 * * *$ & 0.0183 & $0.0641^{* * *}$ \\
\hline & $(0.0164)$ & $(0.0332)$ & $(0.0161)$ \\
\hline \multirow[t]{2}{*}{ Work while studying } & 0.0245 & $0.0776 * * *$ & -0.0411 \\
\hline & $(0.0162)$ & $(0.0280)$ & $(0.0595)$ \\
\hline \multirow[t]{2}{*}{ Dropout } & $-0.0877 * * *$ & $-0.0876^{* * *}$ & $-0.0287 * *$ \\
\hline & $(0.0100)$ & $(0.0281)$ & (0.0139) \\
\hline \multirow[t]{2}{*}{ Unemployed for 3 months or less } & -0.0236 & 0.0074 & $-0.0479 * * *$ \\
\hline & $(0.0299)$ & $(0.0300)$ & $(0.0154)$ \\
\hline \multirow[t]{2}{*}{ Unemployed between 3 and 6 months } & $0.1065^{* * *}$ & $0.1566^{* * *}$ & $0.0847^{* * *}$ \\
\hline & $(0.0350)$ & $(0.0438)$ & $(0.0268)$ \\
\hline \multirow[t]{2}{*}{ Unemployed between 6 and 12 months } & 0.0326 & 0.0489 & 0.0014 \\
\hline & $(0.0524)$ & $(0.0558)$ & $(0.0306)$ \\
\hline \multirow[t]{2}{*}{ Unemployed for more than 12 months } & 0.0300 & 0.0328 & $0.0311^{* * *}$ \\
\hline & $(0.0184)$ & $(0.0275)$ & $(0.0084)$ \\
\hline \multirow[t]{2}{*}{ Main obstacle in finding employment - Lack of skills } & $-0.0758 * * *$ & $-0.1145^{*}$ & $-0.0678 *$ \\
\hline & $(0.0262)$ & $(0.0644)$ & $(0.0355)$ \\
\hline \multirow[t]{2}{*}{ Main obstacle in finding employment - Low wages } & 0.0075 & $-0.1269 * *$ & $0.0917 * *$ \\
\hline & $(0.0334)$ & $(0.0503)$ & $(0.0462)$ \\
\hline \multirow[t]{2}{*}{ Main obstacle in finding employment - Lack of jobs } & -0.0322 & $-0.0924 * * *$ & -0.0128 \\
\hline & $(0.0277)$ & $(0.0277)$ & $(0.0119)$ \\
\hline \multirow[t]{2}{*}{ Egypt } & $0.1722 * * *$ & $0.3785^{* * *}$ & 0.0284 \\
\hline & $(0.0124)$ & $(0.0270)$ & $(0.0229)$ \\
\hline \multirow[t]{2}{*}{ Jordan } & $0.2527 * * *$ & $0.2180 * * *$ & $0.2020 * * *$ \\
\hline & $(0.0226)$ & $(0.0182)$ & $(0.0259)$ \\
\hline \multirow[t]{2}{*}{ Palestine } & $0.1337 * * *$ & $0.0755^{* * *}$ & $0.2021 * * *$ \\
\hline & $(0.0174)$ & $(0.0229)$ & $(0.0266)$ \\
\hline \multirow[t]{2}{*}{ Tunisia } & $0.2043^{* * *}$ & $0.2705^{* * *}$ & $0.1156^{* * *}$ \\
\hline & $(0.0147)$ & $(0.0367)$ & $(0.0140)$ \\
\hline Observations & 2,582 & 1,249 & 1,333 \\
\hline
\end{tabular}

Base categories are described in notes to table 3. Standard errors clustered by country in parentheses. *** $\mathrm{p}<0.01,{ }^{* *} \mathrm{p}<0.05,{ }^{*} \mathrm{p}<0.1$ 
Table 5. Probit marginal effects of the intentions to migrate - heterogenous effects

\begin{tabular}{|c|c|c|c|}
\hline & All & Males & Females \\
\hline Live in rural area & $\begin{array}{c}-0.0196 * \\
(0.0102)\end{array}$ & $\begin{array}{c}0.1523 * * * \\
(0.0315)\end{array}$ & $\begin{array}{c}-0.1121^{* * *} \\
(0.0177)\end{array}$ \\
\hline Age & $\begin{array}{c}0.0020 \\
(0.0028)\end{array}$ & $\begin{array}{l}-0.0006 \\
(0.0048)\end{array}$ & $\begin{array}{c}0.0030 \\
(0.0025)\end{array}$ \\
\hline Female & $\begin{array}{c}-0.3999 * * * \\
(0.0879)\end{array}$ & & \\
\hline Married & $\begin{array}{l}-0.0701 \\
(0.0532)\end{array}$ & $\begin{array}{l}-0.0295 \\
(0.1821)\end{array}$ & $\begin{array}{c}-0.0690^{*} \\
(0.0394)\end{array}$ \\
\hline Have children & $\begin{array}{c}0.0091 \\
(0.0288)\end{array}$ & $\begin{array}{l}-0.0064 \\
(0.1610)\end{array}$ & $\begin{array}{c}0.0248 \\
(0.0305)\end{array}$ \\
\hline Father qualified & $\begin{array}{c}0.0234 \\
(0.0162)\end{array}$ & $\begin{array}{l}0.0521^{*} \\
(0.0282)\end{array}$ & $\begin{array}{l}-0.0069 \\
(0.0079)\end{array}$ \\
\hline Previous mobility & $\begin{array}{l}-0.0200 \\
(0.0425)\end{array}$ & $\begin{array}{l}-0.0499 \\
(0.0649)\end{array}$ & $\begin{array}{c}0.0078 \\
(0.0242)\end{array}$ \\
\hline Good financial conditions & $\begin{array}{c}-0.0756^{* * *} \\
(0.0104)\end{array}$ & $\begin{array}{c}0.0082 \\
(0.0851)\end{array}$ & $\begin{array}{c}-0.0666 * * * \\
(0.0144)\end{array}$ \\
\hline Bad financial conditions & $\begin{array}{l}-0.0026 \\
(0.0477)\end{array}$ & $\begin{array}{c}0.0021 \\
(0.0429)\end{array}$ & $\begin{array}{l}-0.0316 \\
(0.0370)\end{array}$ \\
\hline Tertiary studies x Egypt & $\begin{array}{c}0.0482 * * * \\
(0.0124)\end{array}$ & $\begin{array}{c}0.0286^{* *} \\
(0.0131)\end{array}$ & $\begin{array}{c}0.0937 * * * \\
(0.0103)\end{array}$ \\
\hline Tertiary studies x Jordan & $\begin{array}{c}0.1342 * * * \\
(0.0413)\end{array}$ & $\begin{array}{c}0.1815 * * * \\
(0.0331)\end{array}$ & $\begin{array}{l}-0.0119 \\
(0.0134)\end{array}$ \\
\hline Tertiary studies x Lebanon & $\begin{array}{l}-0.0219 \\
(0.0277)\end{array}$ & $\begin{array}{l}-0.1029 \\
(0.0768)\end{array}$ & $\begin{array}{c}-0.0959 * * * \\
(0.0088)\end{array}$ \\
\hline Tertiary studies x Palestine & $\begin{array}{c}0.1261^{* * *} \\
(0.0476)\end{array}$ & $\begin{array}{c}0.0625 * * \\
(0.0297)\end{array}$ & $\begin{array}{c}-0.0400 * * * \\
(0.0098)\end{array}$ \\
\hline Tertiary studies x Tunisia & $\begin{array}{c}0.0585^{* *} \\
(0.0289)\end{array}$ & $\begin{array}{c}-0.1149 * * * \\
(0.0361)\end{array}$ & $\begin{array}{c}0.0349 * * * \\
(0.0103)\end{array}$ \\
\hline Work while studying & $\begin{array}{c}0.0236 \\
(0.0156)\end{array}$ & $\begin{array}{c}0.0813 * * * \\
(0.0285)\end{array}$ & $\begin{array}{l}-0.0425 \\
(0.0584)\end{array}$ \\
\hline Dropout & $\begin{array}{c}-0.0815^{* * *} \\
(0.0080)\end{array}$ & $\begin{array}{c}-0.0904^{* * *} \\
(0.0314)\end{array}$ & $\begin{array}{c}-0.0487 * * * \\
(0.0169)\end{array}$ \\
\hline Unemployed for 3 months or less & $\begin{array}{l}-0.0244 \\
(0.0310)\end{array}$ & $\begin{array}{c}0.0080 \\
(0.0323)\end{array}$ & $\begin{array}{c}-0.0445^{* * *} \\
(0.0148)\end{array}$ \\
\hline Unemployed between 3 and 6 months & $\begin{array}{c}0.1075^{* * *} \\
(0.0343)\end{array}$ & $\begin{array}{c}0.1601 * * * \\
(0.0414)\end{array}$ & $\begin{array}{c}0.0828 * * * \\
(0.0290)\end{array}$ \\
\hline Unemployed between 6 and 12 months & $\begin{array}{c}0.0318 \\
(0.0535)\end{array}$ & $\begin{array}{c}0.0513 \\
(0.0616)\end{array}$ & $\begin{array}{c}0.0057 \\
(0.0287)\end{array}$ \\
\hline Unemployed for more than 12 months & $\begin{array}{l}0.0310^{*} \\
(0.0178)\end{array}$ & $\begin{array}{c}0.0337 \\
(0.0261)\end{array}$ & $\begin{array}{c}0.0298 * * * \\
(0.0088)\end{array}$ \\
\hline Main obstacle in finding employment - Lack of skills & $\begin{array}{c}-0.0737 * * * \\
(0.0261)\end{array}$ & $\begin{array}{c}-0.1014^{*} \\
(0.0567)\end{array}$ & $\begin{array}{c}-0.0727 * * \\
(0.0315)\end{array}$ \\
\hline Main obstacle in finding employment - Low wages & $\begin{array}{c}0.0070 \\
(0.0329)\end{array}$ & $\begin{array}{c}-0.1261 * * \\
(0.0500)\end{array}$ & $\begin{array}{l}0.0918^{*} \\
(0.0470)\end{array}$ \\
\hline Main obstacle in finding employment - Lack of jobs & $\begin{array}{l}-0.0319 \\
(0.0281)\end{array}$ & $\begin{array}{c}-0.0917 * * * \\
(0.0281)\end{array}$ & $\begin{array}{l}-0.0143 \\
(0.0120)\end{array}$ \\
\hline Egypt & $\begin{array}{c}0.1718 * * * \\
(0.0092)\end{array}$ & $\begin{array}{c}0.3705 * * * \\
(0.0207)\end{array}$ & $\begin{array}{l}-0.0300 \\
(0.0286)\end{array}$ \\
\hline Jordan & $\begin{array}{c}0.2116 * * * \\
(0.0198)\end{array}$ & $\begin{array}{c}0.1821 * * * \\
(0.0218)\end{array}$ & $\begin{array}{c}0.2104 * * * \\
(0.0253)\end{array}$ \\
\hline Palestine & $\begin{array}{c}0.1051 * * * \\
(0.0200)\end{array}$ & $\begin{array}{c}0.0637 * * * \\
(0.0231)\end{array}$ & $\begin{array}{c}0.2319 * * * \\
(0.0339)\end{array}$ \\
\hline Tunisia & $\begin{array}{c}0.1964 * * * \\
(0.0119)\end{array}$ & $\begin{array}{c}0.2843 * * * \\
(0.0396)\end{array}$ & $\begin{array}{c}0.0799 * * * \\
(0.0143)\end{array}$ \\
\hline Observations & 2,582 & 1,249 & 1,333 \\
\hline
\end{tabular}

Base categories are described in notes to table 3. Standard errors clustered by country in parentheses. $* * * \mathrm{p}<0.01, * * \mathrm{p}<0.05, * \mathrm{p}<0.1$ 
Table 6. Probit marginal effects of the intentions to migrate abroad of youth NEETs

\begin{tabular}{|c|c|c|c|}
\hline & All & Males & Females \\
\hline Live in rural area & $\begin{array}{c}0.2990 * * * \\
(0.0198)\end{array}$ & $\begin{array}{c}0.3468 * * * \\
(0.0326)\end{array}$ & $\begin{array}{c}0.1033 * * * \\
(0.0236)\end{array}$ \\
\hline Age & $\begin{array}{c}0.0129 * * * \\
(0.0033)\end{array}$ & $\begin{array}{c}0.0144 * * * \\
(0.0046)\end{array}$ & $\begin{array}{c}0.0034 \\
(0.0025)\end{array}$ \\
\hline Female & $\begin{array}{c}-0.2913 * * * \\
(0.0717)\end{array}$ & & \\
\hline Married & $\begin{array}{l}-0.0174 \\
(0.0917)\end{array}$ & $\begin{array}{c}0.0277 \\
(0.1273)\end{array}$ & $\begin{array}{l}-0.0101 \\
(0.0258)\end{array}$ \\
\hline Have children & $\begin{array}{l}-0.0366 \\
(0.0501)\end{array}$ & $\begin{array}{c}-0.1642^{* * *} \\
(0.0538)\end{array}$ & $\begin{array}{l}-0.0026 \\
(0.0122)\end{array}$ \\
\hline Father qualified & $\begin{array}{l}-0.0094 \\
(0.0147)\end{array}$ & $\begin{array}{l}-0.0085 \\
(0.0250)\end{array}$ & $\begin{array}{l}-0.0111 \\
(0.0095)\end{array}$ \\
\hline Previous mobility & $\begin{array}{c}0.0049 \\
(0.0682)\end{array}$ & $\begin{array}{c}0.0465 \\
(0.1236)\end{array}$ & $\begin{array}{l}-0.0012 \\
(0.0184)\end{array}$ \\
\hline Good financial conditions & $\begin{array}{c}0.0491 \\
(0.0472)\end{array}$ & $\begin{array}{c}0.1039 * * \\
(0.0405)\end{array}$ & $\begin{array}{l}-0.0138 \\
(0.0087)\end{array}$ \\
\hline Bad financial conditions & $\begin{array}{c}0.1013 * * * \\
(0.0281)\end{array}$ & $\begin{array}{c}0.1332 * * * \\
(0.0386)\end{array}$ & $\begin{array}{c}-0.0087^{*} \\
(0.0052)\end{array}$ \\
\hline Tertiary studies x Egypt & $\begin{array}{l}-0.0388 \\
(0.0397)\end{array}$ & $\begin{array}{c}0.0038 \\
(0.0301)\end{array}$ & \\
\hline Tertiary studies x Jordan & $\begin{array}{c}0.1640 * * \\
(0.0834)\end{array}$ & $\begin{array}{c}0.0296 \\
(0.0614)\end{array}$ & $\begin{array}{c}0.9981 * * * \\
(0.0016)\end{array}$ \\
\hline Tertiary studies x Palestine & $\begin{array}{l}0.2313^{*} \\
(0.1281)\end{array}$ & $\begin{array}{c}0.2674 * * \\
(0.1062)\end{array}$ & $\begin{array}{c}0.0067 \\
(0.0082)\end{array}$ \\
\hline Tertiary studies x Tunisia & $\begin{array}{c}-0.1185^{* *} \\
(0.0539)\end{array}$ & $\begin{array}{c}-0.3474 * * * \\
(0.0171)\end{array}$ & $\begin{array}{c}0.0240 \\
(0.0149)\end{array}$ \\
\hline Work while studying & $\begin{array}{l}0.2996 * \\
(0.1578)\end{array}$ & $\begin{array}{c}0.3617 * * \\
(0.1462)\end{array}$ & $\begin{array}{c}0.0136 \\
(0.0403)\end{array}$ \\
\hline Dropout & $\begin{array}{l}0.1001^{*} \\
(0.0573)\end{array}$ & $\begin{array}{c}0.0902 \\
(0.0779)\end{array}$ & $\begin{array}{c}0.1158 * * * \\
(0.0406)\end{array}$ \\
\hline Unemployed for 3 months or less & $\begin{array}{c}0.0008 \\
(0.0945)\end{array}$ & $\begin{array}{l}-0.0635 \\
(0.0862)\end{array}$ & $\begin{array}{c}0.1368 * * * \\
(0.0262)\end{array}$ \\
\hline Unemployed between 3 and 6 months & $\begin{array}{c}0.1100 * * * \\
(0.0290)\end{array}$ & $\begin{array}{c}0.1082 * * * \\
(0.0340)\end{array}$ & \\
\hline Unemployed between 6 and 12 months & $\begin{array}{c}0.2488 * * * \\
(0.0488)\end{array}$ & $\begin{array}{c}0.2827 * * * \\
(0.0477)\end{array}$ & $\begin{array}{c}0.0354 \\
(0.0452)\end{array}$ \\
\hline Unemployed for more than 12 months & $\begin{array}{c}0.1034 * * * \\
(0.0168)\end{array}$ & $\begin{array}{c}0.1048 * * * \\
(0.0126)\end{array}$ & $\begin{array}{l}0.0176 * \\
(0.0104)\end{array}$ \\
\hline Main obstacle in finding employment - Lack of skills & $\begin{array}{c}0.0413 \\
(0.0459)\end{array}$ & $\begin{array}{c}0.0902 * * * \\
(0.0307)\end{array}$ & $\begin{array}{c}-0.0147^{*} \\
(0.0084)\end{array}$ \\
\hline Main obstacle in finding employment - Low wages & $\begin{array}{l}-0.0096 \\
(0.0162)\end{array}$ & $\begin{array}{c}0.0114 \\
(0.0281)\end{array}$ & $\begin{array}{c}-0.0186 * \\
(0.0098)\end{array}$ \\
\hline Main obstacle in finding employment - Lack of jobs & $\begin{array}{c}0.1816 * * * \\
(0.0565)\end{array}$ & $\begin{array}{c}0.2415^{* * *} \\
(0.0610)\end{array}$ & $\begin{array}{c}0.0240 \\
(0.0204)\end{array}$ \\
\hline Egypt & $\begin{array}{c}-0.1528 * * * \\
(0.0221)\end{array}$ & $\begin{array}{c}-0.1721^{* * *} \\
(0.0163)\end{array}$ & $\begin{array}{l}-0.0377 \\
(0.0245)\end{array}$ \\
\hline Jordan & $\begin{array}{c}-0.2491 * * * \\
(0.0093)\end{array}$ & $\begin{array}{c}-0.3556 * * * \\
(0.0236)\end{array}$ & $\begin{array}{c}-0.1146^{* *} \\
(0.0498)\end{array}$ \\
\hline Palestine & $\begin{array}{c}0.1187 * * * \\
(0.0364)\end{array}$ & $\begin{array}{c}0.0635 \\
(0.0595)\end{array}$ & $\begin{array}{c}0.0392 \\
(0.0412)\end{array}$ \\
\hline Tunisia & $\begin{array}{c}0.0917 * * * \\
(0.0280)\end{array}$ & $\begin{array}{c}0.1231 * * * \\
(0.0362)\end{array}$ & $\begin{array}{r}-0.0013 \\
(0.0103)\end{array}$ \\
\hline Observations & 795 & 546 & 205 \\
\hline
\end{tabular}

Tertiary studies x Lebanon not included as all graduates would prefer to move internally. The same applies to Tertiary studies x Egypt for females. Base categories are described in notes to table 3. Standard errors clustered by country in parentheses. ${ }^{* * *} \mathrm{p}<0.01,{ }^{* *} \mathrm{p}<0.05,{ }^{*} \mathrm{p}<0.1$ 


\section{Appendix 1. Descriptive statistics}

\begin{tabular}{|c|c|c|c|c|}
\hline & Mean & Std. Dev. & Min. & Max. \\
\hline Would you consider moving to find work? $($ Yes=1) & 0.3079 & 0.4617 & 0 & 1 \\
\hline Would you consider moving to another country to find work? (Yes=1) & 0.1170 & 0.3214 & 0 & 1 \\
\hline Gender (Female $=1)$ & 0.5163 & 0.4998 & 0 & 1 \\
\hline Age (in years) & 23.2425 & 3.5179 & 15 & 29 \\
\hline Marital status (Married =1) & 0.2169 & 0.4122 & 0 & 1 \\
\hline Do you have children? (Yes=1) & 0.1789 & 0.3834 & 0 & 1 \\
\hline Number of children & 0.3919 & 0.9573 & 0 & 8 \\
\hline Rural area (Yes $=1)$ & 0.4845 & 0.4999 & 0 & 1 \\
\hline Did you live your entire life in the same place? $(\mathrm{No}=1)$ & 0.1452 & 0.3524 & 0 & 1 \\
\hline Financial situation of the family - Good or very good =1 & 0.1929 & 0.3946 & 0 & 1 \\
\hline Financial situation of the family - Bad or very bad =1) & 0.2486 & 0.4323 & 0 & 1 \\
\hline Father successfully completed tertiary level of education & 0.2347 & 0.4239 & 0 & 1 \\
\hline Mother successfully completed tertiary level of education & 0.1615 & 0.3681 & 0 & 1 \\
\hline Primary level of formal education or less & 0.3122 & 0.4635 & 0 & 1 \\
\hline Secondary level of formal education & 0.3633 & 0.4810 & 0 & 1 \\
\hline Tertiary level of formal education & 0.3246 & 0.4683 & 0 & 1 \\
\hline Did you work during your studies? (Yes=1) & 0.1034 & 0.3046 & 0 & 1 \\
\hline Interrupted studies before having completed them & 0.4194 & 0.4936 & 0 & 1 \\
\hline Have you ever worked? (Yes=1) & 0.5531 & 0.4973 & 0 & 1 \\
\hline Have you looked for a job in the last 30 days? (Yes=1) & 0.7266 & 0.4458 & 0 & 1 \\
\hline Unemployed and actively looking for work for 3 months or less & 0.1123 & 0.3158 & 0 & 1 \\
\hline Unemployed and actively looking for work between 3 and 6 months & 0.0655 & 0.2474 & 0 & 1 \\
\hline Unemployed and actively looking for work between 6 and 12 months & 0.1108 & 0.3139 & 0 & 1 \\
\hline Unemployed and actively looking for work for 12 months or more & 0.4558 & 0.4981 & 0 & 1 \\
\hline Have you ever turned down a job offered to you? (Yes=1) & 0.1112 & 0.3144 & 0 & 1 \\
\hline What is the main obstacle in finding employment? Lack of skills & 0.1003 & 0.3005 & 0 & 1 \\
\hline What is the main obstacle in finding employment? Low wages & 0.1940 & 0.3955 & 0 & 1 \\
\hline What is the main obstacle in finding employment? Lack of jobs & 0.3757 & 0.4844 & 0 & 1 \\
\hline Egypt & 0.0705 & 0.2560 & 0 & 1 \\
\hline Jordan & 0.2436 & 0.4293 & 0 & 1 \\
\hline Lebanon & 0.2188 & 0.4135 & 0 & 1 \\
\hline Palestine & 0.0000 & 0.0000 & 0 & 1 \\
\hline Tunisia & 0.2804 & 0.4493 & 0 & 1 \\
\hline Number of observations & 2,582 & & & \\
\hline
\end{tabular}

Source: Own elaboration from ILO-SWTS 2013-2015 


\section{Appendix 2. Variable definition in the SWTS original microdata files}

\begin{tabular}{|c|c|c|c|c|c|}
\hline & $\begin{array}{l}\text { EGYPT } \\
2015 \\
\end{array}$ & $\begin{array}{l}\text { JORDAN } \\
2015 \\
\end{array}$ & $\begin{array}{l}\text { LEBANON } \\
2015 \\
\end{array}$ & $\begin{array}{l}\text { PALESTINE } \\
2015 \\
\end{array}$ & $\begin{array}{l}\text { TUNISIA } \\
2013 \\
\end{array}$ \\
\hline weight & wgt & wgt & $\mathrm{w}$ & wgt & weight \\
\hline rural/urban & rururb & rururb & q5 & rururb & region \\
\hline Sex & $\operatorname{sex}$ & $\operatorname{sex}$ & b4 & $\operatorname{sex}$ & $\operatorname{sex}$ \\
\hline Gender & age & age & b2 & age & age \\
\hline Did you live your entire life in the same place? & a104 & q210 & b5 & b01 & move_previously \\
\hline What is your marital status? & a108 & q207 & b9 & b04 & marital \\
\hline Do you have children? & a110 & q209 & b11 & b07 & children \\
\hline How would you describe the financial situation of your family? & a201 & q213 & b12 & b08 & hh_situ_financial \\
\hline What is the highest level of formal education successfully completed by your father? & a401 & q222 & $\mathrm{b} 21$ & b13 & father_edu \\
\hline Are you currently enrolled in formal education or in any training program? & $\mathrm{C03}$ & c1 & c3 & c01 & currently_attend \\
\hline What is the highest level of education or training that you have successfully completed? & highestlevel_comp & c11 & c11 & c10 & highestlevel_comp \\
\hline Did you work during your studies? & a514 & q313 & c14 & c13 & work_studying \\
\hline Have you looked for a job / started a project or business in the last 30 days? & seekingjob & q601 & f1 & f01 & seekingjob \\
\hline How long have you been unemployed and actively looking for work? & length_search_job & q609 & f8 & f11 & length_search_job \\
\hline Would you have been available to start a job last week if you were offered to? & availability & q610 & f9 & $\mathrm{f} 12$ & disponw \\
\hline Have you ever turned down a job offered to you? & a918 & q617 & f17 & $\mathrm{f} 20$ & refusnw \\
\hline Would you consider moving to find work? & a923 & q622a & $\mathrm{f} 23$ & f26 & movingnw \\
\hline What is the main obstacle in finding employment? & a924 & $\mathrm{q} 623$ & $\mathrm{f} 24$ & $\mathrm{f} 27$ & obstaclenw \\
\hline
\end{tabular}

